Acta. vet. scand. $1961,2,120-128$.

From the State Veterinary Institute for Virus Research, Lindholm per Kalvehave, Denmark.

\title{
SOME OBSERVATIONS CONCERNING TITRATION OF FOOT-AND-MOUTH DISEASE VIRUS IN 1-10 DAY OLD MICE
}

By

B. Chr. H. Gierløff

For about the last ten years unweaned white mice have successfully been used as experimental animals for the titration of foot-and-mouth disease (FMD) virus of different strains and origins. In the beginning, Skinner (1951) used mice 14-18 days old, but later it was found that 7-10 day old mice were more susceptible to infection. After some years 6-8 day old mice were preferred, "because mice older than nine days had shown increasing resistance to infection and a lengthening of the period of incubation, while mice younger than six days showed no increase in susceptibility to infection" (1953). In 1957 Willems stated that according to the technique proposed by Skinner, they used litters of mice not exceeding ten days of age. A year later the institute in Belgium appeared to prefer one day old litters. As a basis for estimating the neutralizing activity of immune serums, the Dutch foot-and-mouth disease institute appears to choose the unweaned mice as young as possible. In our institute mice used as experimental animals with FMD virus have been from four to eight days old (Michelsen). As many experiments, however, require $20-40$ litters $(160-320$ mice $)$ at a time, it has often been necessary, because of insufficient breeding capacity, to include litters of different age in one experiment. The main aim of the present work, therefore, was to try the above age limits of the unweaned mice that are susceptible to a FMD infection and investigate the possibility of determining the widest usable limits, an adapted form of the Skinner technique being used. 


\section{MATERIAL AND TECHNIQUE}

For the inoculations virus strains of three different immunological types were used, eight samples of virus in all, falling into three categories (Table 1).

T a b l e 1. Data regarding the eight FMD virus samples used.

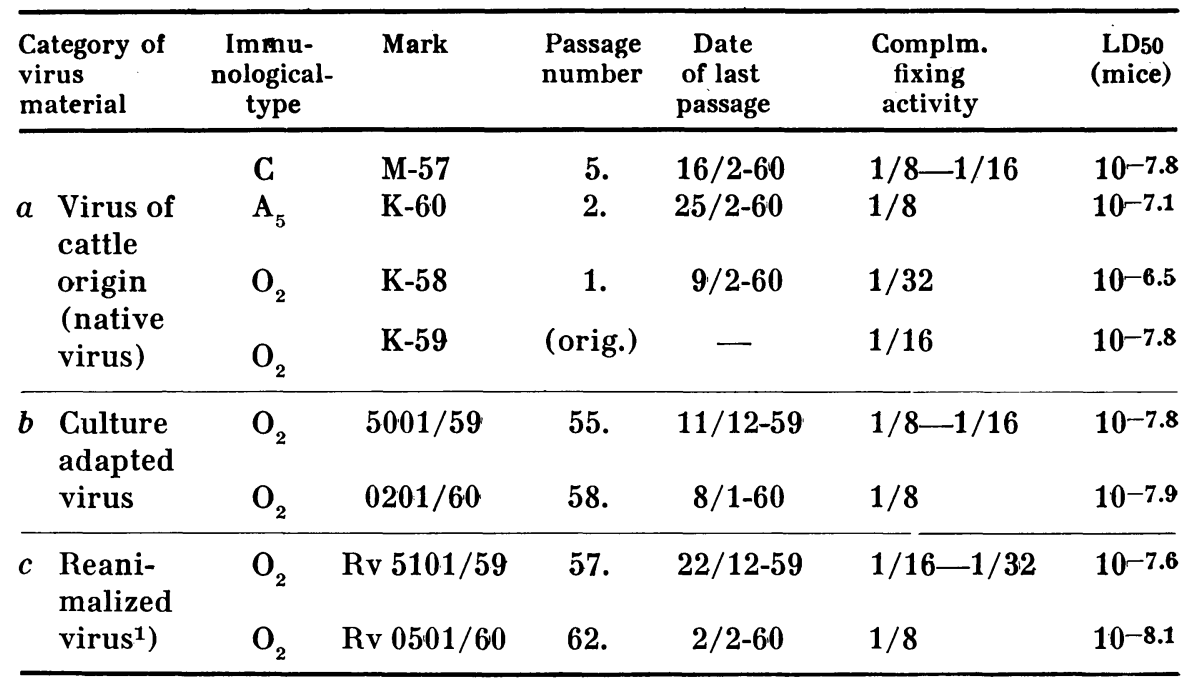

1) Reanimalized virus is culture adapted virus passed once in cattle.

Material of the categories $a$ and $c$ were minced with scissors, ground in a morter with $M / 50$ phosphate buffer $(1+9)$, and centrifugalized twice in a Wifug centrifuge. Virus of category $b$ (supernatant) was centrifugalized once in an Alfa-Laval centrifuge just before titration. The standard dose of inoculation throughout this work was 0.1 cc. $^{1}$ ) injected intraperitoneally.

The applied mice were a Swiss strain from our own breeding. Because of the high sensitivity to foot-and-mouth disease virus and the apparently regular manner in which mice of different litters from this breeding used to develop symptoms the litters were not randomized and re-distributed before inoculation. Care was taken that every litter used consisted of eight mice originating just from one and the same mother. In this work few

1) In another similar experiment the standard dose of inoculation was $0.03 \mathrm{cc}$. The titration results in respect to $\mathrm{LD}_{50}$ showed values with remarkably higher standard errors than in the above experiments with 0.1 cc. used as the standard dose of inoculation. 


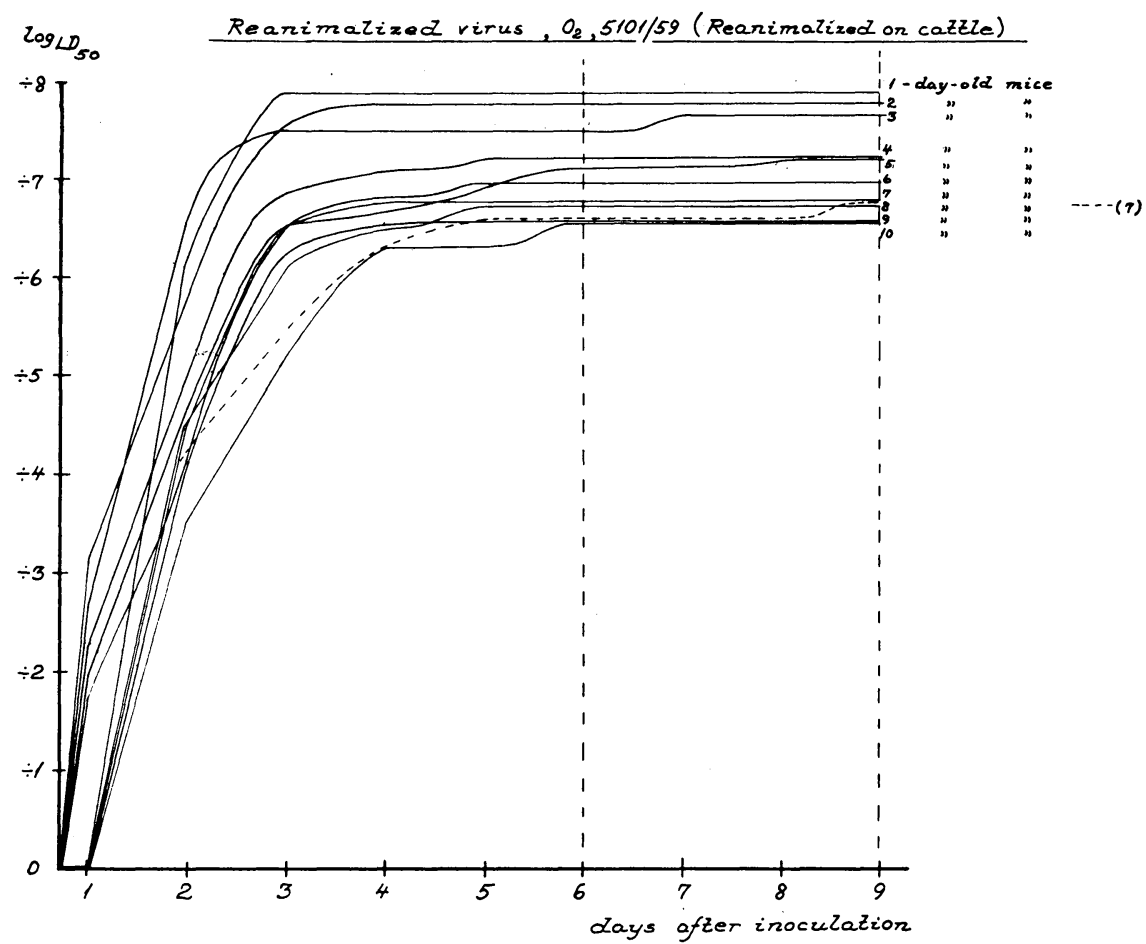

F ig. 1. Daily rate of mortality of $1-10$ day old white mice inoculated with reanimalized FMD virus. The susceptibility to infection is decreasing with an increase in the age of inoculated mice. One litter of 7 day old mice inoculated with virus diluted $10^{-4}$ (box 275, 25/1-60) showed resistance to infection with a lengthening of the period of incubation, but without any influence on the final rate of mortality (broken line).

litters showed an extraordinarily strong resistance to FMD virus dying 2-4 days later than expected (Fig. 1, broken line), or did not die at all, but such phenomenons caused no difficulties in the estimation of the final rate of mortality.

The eight virus strains were titrated on six hundred and fourty litters of 1-10 day old mice in all. One at a time each of the strains was titrated on the same day on ten groups of eight litters each, the groups ranging from one to ten days of age. Twice a day during the following nine days the litters were inspected, and the number of 1) dead, 2) paralysed, 3) partly eaten, or 4) missing mice was determined. The fifty per cent end 

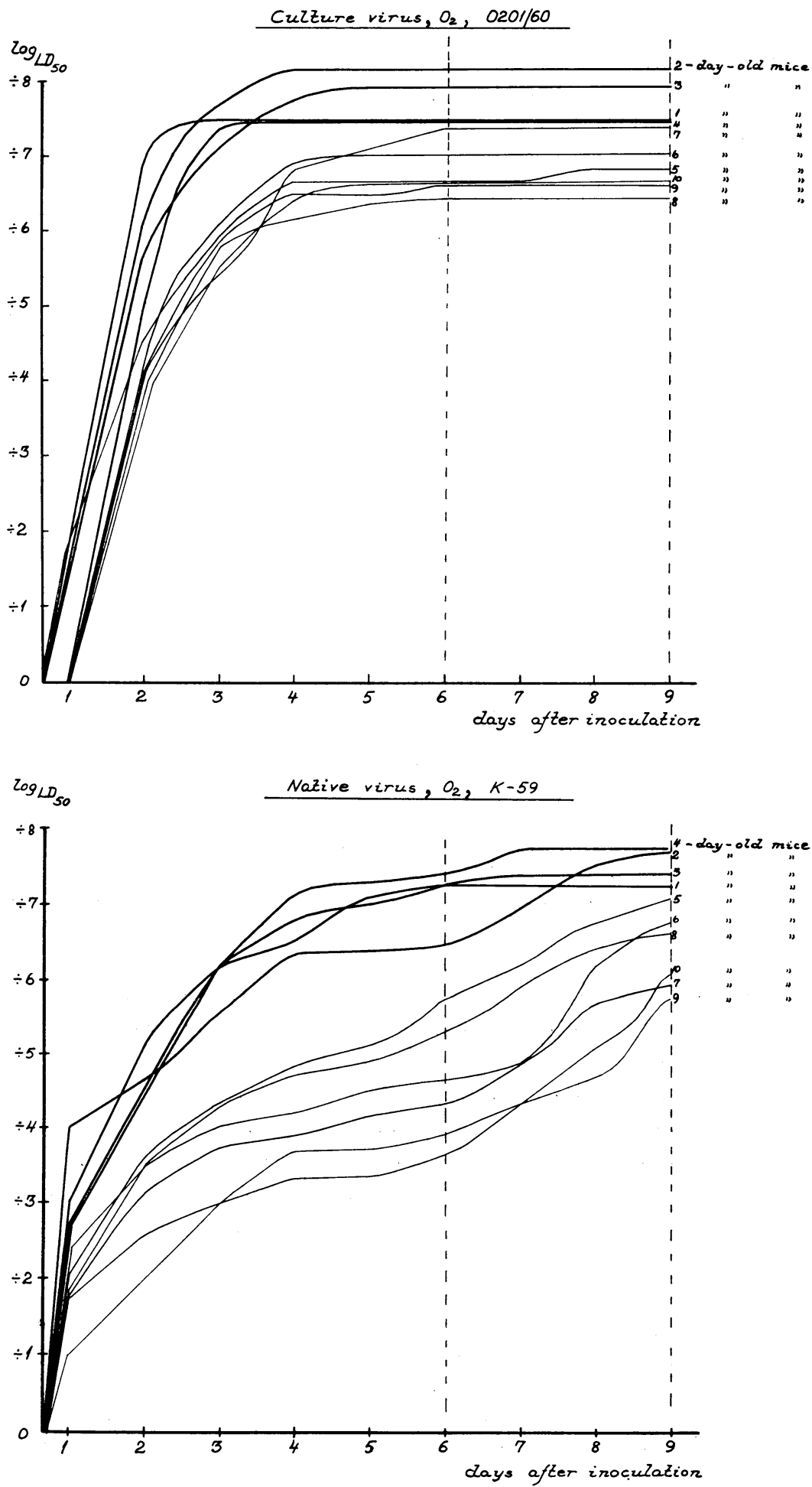

F i g. 2 a n d 3. Daily rate of mortality of 1-10 day old white mice inoculated with FMD virus (culture and native virus respectively). There is a distinct difference in susceptibility to infection between 1 -4 day old mice and older ones. 




F i g. 4. Daily rate of mortality in the eight samples of FMD virus when titrated in 2 day old mice. Culture adapted virus appears more infective to mice than the native virus, even when reanimalized.

point in regard to the two first ${ }^{1}$ ) of the above categories was estimated $(2,4)$ and the results expressed by $\log \mathrm{LD}_{50}$ drawn up into graphs (Fig. 1-3).

Mice dying on the first day after inoculation were included in the estimation of $\mathrm{LD}_{50}$, because tissue material from the carcasses, when ground with quartz, suspended in $M / 25$ phosphate buffer, and subsequently passed twice in mice, produced specific complement fixing antibodies in these animals.

1) With one of the strains $\left(\mathrm{O}_{2}, \mathrm{~K}-59\right)$, the fifty per cent end point estimated on the seventh day $p . i$. with mice of the above category 1 only, and with mice from both the categories 1 and 2, showed a log 2.0 $\mathrm{LD}_{50}$ difference. Mice of category 2 amounted to 57 paralysed mice of which $51(89.5 \%)$ died within two days, and the rest within four days. Of ten mice which did not thrive, but which were not paralysed, no one died, and none of these mice were included in the estimation of fifty per cent end point. 
Difference in morzalizy wizhin mice varying 2 , 4 and 10 days in age

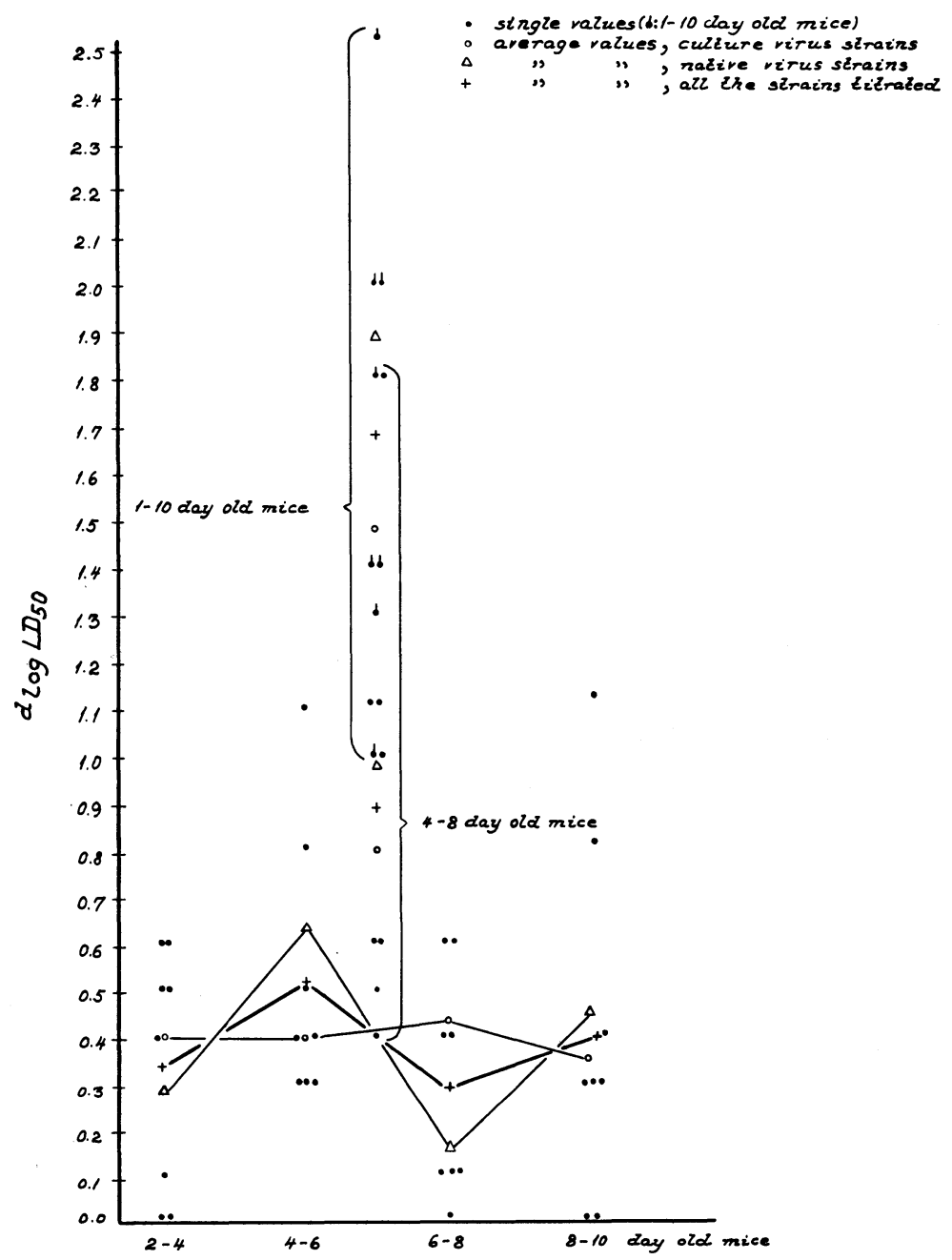

F i g. 5. Average values of difference $d_{\log L D_{50}}$ in mortality between litters of mice varying 2 days in age when used for titration of FMD virus. The curve of the average differences has its peak with the 4-6 day old mice, and its lowest values with the $6-8$ day old and $2-4$ day old ones, especially when native virus is employed, whereas the culture virus gives rather uniform results.

When titrating the virus in mice varying from $4-8$ or $1-10$ days in age, the titration results may vary up to five times the maximum average value in mice varying 2 days in age (the single average values are marked with $\mathbf{a}+$ ). 
The difference in mortality between the groups of $2 \& 4$ day old, $4 \& 6$ day old, $6 \& 8$ day old, $8 \& 10$ day old, $4 \& 8$ day old and $1 \& 10$ day old mice respectively, was for all the eight virus strains estimated on the 9 th day after inoculation. The difference expressed by $d_{\log L D_{50}}$ are represented in a graph (Fig. 5).

\section{RESULTS}

In the majority of cases, the graphs gave the same picture: 1) The susceptibility to infection of $1-10$ day old mice was decreasing with an increase in age of the inoculated mice (Fig. 1). 2) The $2-4$ day old mice seemed much more susceptible to the infection than older mice with a distinct dividing space between the curves of the daily rate of mortality within the two categories of mice (Fig. 2 and 3). 3) The tested culture virus was highly infective to the mice, and produced the final results of fifty per cent end point within 4-6 days (Fig. 2). 4) The original native virus appeared less infective to mice (Fig. 4), and rendered necessary 6-9 days of inspection before the titration could be said to be finished (Fig. 3). 5) The graphs of $\log _{\mathrm{LD}}$ also showed that seven out of eight different curves concerning 1 day old mice were about the same or lower ordinate values than the curves concerning 4 days old mice.

When the difference of age of the inoculated litters was only 2 days, the $d_{\log L D_{50}}$ had its lowest average values when titration was done on $6-8$ day old and $2-4$ day old mice $(0.29$ and 0.34 respectively) and summit on $4-6$ day old mice with rather great variations in the single values (Fig. 5). The latter is in accordance with the picture of a distinct space between curves of the daily rate of mortality of 2-4 day old mice and older ones. - When the difference of age of the inoculated mice was 4 days or more, the $d_{\log L D_{s 0}}$ reached average values as high as $1.7 \log$ with $\log 2.5$ as the highest single value (type $A_{5}$ ) which is about five times the highest average value in mice varying only 2 days in age.

Here too there seems to be a marked difference between native virus and culture adapted virus, the latter giving the most homogeneous results $(0.35-0.43 \mathrm{log})$ within the four groups of mice varying 2 days in age, whereas the former gave some greater variations $(0.15-0.63 \log )$. 


\section{CONCLUSIONS}

Titration of FMD virus in 1 day old white mice must be considered a bad procedure, because the handling of such mice may cause some difficulties, and as a rule more or less of the inoculated virus suspension is lost through the wound after the injection, which may be the reason why in this experiment the fifty per cent end point in such mice was lower than in $2-4$ day old ones.

The 2-4 day old mice are considered suitable for titration of FMD virus, because mice of different age within these age limits show a low difference in susceptibility to infection and appeare to be the most susceptible to FMD virus.

The 6-8 day old mice show the lowest difference in susceptibility to infection, especially when native virus is employed, but these mice are not so sensitive to the virus.

A difference in age of more than two days should be avoided, especially when the youngest and the oldest litter of mice separately falls within the age limits $1-4$ days and 6-10 days respectively.

Nine days of inspection after inoculation seems necessary in order to get the lowest variation in the final rate of mortality $\left(L D_{50}\right)$, especially when the virus seems not to be highly infective.

If lack of time or room makes it necessary to bring a titration to an early end, the rate of mortality within the first four days may show if an experiment can securely be finished within 6 days.

\section{REFERENCES}

Michelsen, E.: Personal communication.

Reed, L. J. and H. Muench: Amer. J. Hyg. 1938, 27, 493.

Skinner, H. H.: Proc. Roy Soc. Med. 1951, 44, 1041.

Skinner, H. H.: XVth Int. Vet. Congress, Stockholm 1953.

Willems, R. and J. Leunen: Application of the Frenkel method for cultivating the foot-and-mouth disease virus results obtained at the State Veterinary Research Laboratory, Uccle, Brussels, Methods of typing and cultivating of foot-and-mouth disease viruses, project no. 208, Paris, 1957. 


\section{SUMMARY}

White mice 1-10 days old were used for the titration of footand-mouth disease (FMD) virus of different strains and origins.

It was found that the susceptibility to infection of these mice was decreasing with an increase in age of the mice and that a difference in age of the mice of more than two days should be avoided when titrating FMD-virus. Mice 2-4 days old are considered best fit for the titration.

The culture adapted FMD-virus strains appeared more infective to the mice than the cattle adapted ones - even when reanimalized.

Nine days of inspection after inoculation seemed necessary in order to get the final values of mortality $\left(L D_{50}\right)$, especially when the virus was considered not to be highly infective, but the rate of mortality within the first four days showed if a titration experiment could securely be finished within 6 days.

\section{ZUSAMMENFASSUNG}

Maul- und Klauenseuchevirus verschiedenen Typs und Ursprungs titriert an weissen Mäusen in variierendem Alter von 1-10 Tagen.

Es wird nachgewiesen, dass die Empfänglichkeit der Maus für die Infektion mit Maul- und Klauenseuchevirus mit steigendem Alter der Maus wesentlich abnimmt, und dass der Altersunterschied der Maus beim Gebrauch derselben Titrierung 2 Tage nicht überschreiten soll.

2-4 Tage alte Mäuse scheinen sich für die Titrierung des Maulund Klauenseuchevirus am besten zu eignen.

Kulturvirus scheint für Mäuse pathogener als natives Virus selbst nach einer Rückübertragung des Virus auf das Rind zu sein.

Die hier durchgeführten Titrierungstechnik erfordern eine Beobachtungszeit von 9 Tagen; die Mortalität $\left(L D_{50}\right)$ unter den Mäusen in den ersten vier Tagen deutet jedoch daran, wenn das Virus so pathogen ist, dass der Versuch am 6. Tage abgeschlossen werden kann.

\section{RESUMÉ}

Mund- og klovsygevirus af forskellig type og oprindelse titreret på hvide mus, som varierede $i$ alder fra 1-10 dage.

Det påvises, at musenes modtagelighed for infektion med mk-virus aftager væsentligt med en stigning i musenes alder, og at forskellen $i$ alder på mus anvendt til samme titrering ikke bør overskride 2 dage.

Mus, der er fra 2-4 dage gamle, synes bedst egnede til titrering af mk-virus.

Kulturvirus synes at være mere patogent for musene end naturvirus selv efter reanimalisering på kvæg.

Titreringer som her gennemf $\varnothing$ rt kræver 9 dages observationstid, dog antyder dødeligheden $\left(L D_{50}\right)$ blandt musene de f $\varnothing$ rste fire dage, om virus er så patogent, at forsøget kan afsluttes på 6 dage. 